\title{
Vestida de saudade viva: o sentimento saudoso como tra(d)ição na poesia de Maria Teresa Horta
}

\section{Dressed in live longing: the nostalgic sentiment as tradition in the poetry of Maria Teresa Horta}

Durval Muniz de Albuquerque Júnior*

Resumo: Esse texto se inscreve no campo dos estudos sobre os usos do passado. Tomando como material de análise a obra da poeta portuguesa Maria Teresa Horta, notadamente seus livros Cronista não é recado, Minha senhora de mim, Novas cartas portuguesas e Educação Sentimental, analisa como ela se utiliza de gêneros narrativos, tanto literários, quanto memorialísticos e historiográficos considerados tradicionais para realizar uma releitura crítica da história das mulheres e da escrita sobre e de mulheres em Portugal. Sua obra redimensiona o uso saudosista de dados topos narrativos e das mitologias nacionalista e conservadora que sustentaram, ao mesmo tempo, o regime salazarista e a exclusão social das mulheres. Sua escrita realiza uma traição à tradição e explicita que, nem sempre, saudade quer dizer regresso. .

Palavras-chave: saudade; tradição; traição; modelos narrativos; feminismo

\footnotetext{
* Doutor em História pela Universidade de Campinas (UNICAMP) e atualmente professor permanente da Universidade Federal do Rio Grande do Norte (UFRN/Natal) e do Programa de Pós-Graduação em História da Universidade Federal de Pernambuco (UFPE). Tem experiência na área de História, com ênfase em Teoria e Filosofia da História, atuando principalmente nos seguintes temas: gênero, nordeste, masculinidade, identidade, cultura, biografia histórica e produção de subjetividade. E-mail: durvalaljr@gmail.com
} 


\begin{abstract}
This text falls within the field of studies on the uses of the past. Taking as material for analysis the work by Portuguese poet, Maria Teresa Horta, notably her books Cronista não é recado, Minha senhora de mim, Novas cartas portuguesas and Educação Sentimental, there is an analysis of how she makes use of narrative genres, both literary, and memorialistic and historiographical, considered traditional in performing a critical rereading of the history of women and writing on and about women in Portugal. Her work reassesses the nostalgic use of narrative data and the nationalistic and conservative mythologies that sustained the Salazarist regime, and the social exclusion of women, at the same time. Her writing carries out a betrayal of tradition and explains that longing does not always mean regression.
\end{abstract}

Keywords: longing; tradition; betrayal; narrative models; feminism.

Quanta saudade da seda do vestido que à pele adere num outro abraço (Ritual do Amor)

\title{
Saudade não é regresso
}

No ano de 1967, a poetisa e escritora portuguesa Maria Teresa Horta lança o livro de poesias intitulado Cronista não é recado ${ }^{l}$. Desde o título se pode perceber a relação crítica que sua obra vai estabelecer com uma dada tradição narrativa, com um dos gêneros narrativos que foi fundamental na construção das versões oficiais sobre a história nacional: as crônicas coloniais. As narrativas que nos séculos XVI e XVII registraram o que seriam os feitos de reis, vice-reis, navegadores, capitães-mores, fidalgos, que buscaram imortalizar as façanhas de homens de estirpe e de escol, construindo através de narrativas épicas e lendárias uma dada versão do passado. Ao afirmar, desde o título de seu livro, que cronista não é recado, ou seja, que as crônicas coloniais não deveriam ser lidas inocentemente como narrativas realistas e veristas sobre o passado nacional, Maria Teresa Horta chama atenção para um elemento, muitas vezes, negligenciado pelos debates no campo da historiografia, notadamente num país como o Portugal, da década de sessenta, ainda submetido ao regime salazarista: o papel da linguagem, o papel da narrativa na construção do que consideramos ser o passado, a dimensão ficcional presentes nesses escritos, tomados como relatos verídicos sobre a história pátria. Esse livro é muito significativo para entendermos o tipo de relação que a obra poética e literária 
de Maria Teresa Horta vai estabelecer com a tradição no campo das letras de seu país, como também para tratarmos dos usos dessa tradição, do passado, da história, que realiza em seus escritos. Esse livro, assim como os três que lhe seguirão, Minha senhora de $\mathrm{mim}^{2}$, publicado em 1971, Novas Cartas Portuguesas $^{3}$ (escrito em conjunto com Maria Isabel Barreno e Maria Velho da Costa), publicado em 1972 e Educação sentimental ${ }^{4}$, publicado em 1975, nos permitem tratar, também, dos usos que essa poeta faz da temática da saudade, tema recorrente na tradição literária portuguesa, que explicita a relação que ela estabelece com os tempos, a maneira como em sua obra aparecem articulados o passado, o presente e o futuro.

Tendo frequentado a Faculdade de Letras de Lisboa, no fim dos anos cinquenta $^{5}$, teve contato com a obra de autores como Roland Barthes e Maurice Blanchot, que chamavam a atenção para a centralidade da linguagem na construção e também no questionamento daquilo que os homens e mulheres julgavam ser sua realidade. Com os textos do semiólogo homossexual, Roland Barthes, e por que não com sua própria experiência de mulher, Maria Teresa Horta aprendeu que a dominação masculina se alojava na própria linguagem, que a ordem simbólica das sociedades patriarcais reservava lugares marcados e subalternos para as mulheres, para o feminino. A opressão feminina tinha amparo na ordem dos discursos, a subordinação social das mulheres se amparava na hegemonia cultural do masculino. Portanto, o que se nomeava de tradição, seja cultural, seja literária, seja histórica trazia a marca da dominação masculina e da exclusão das mulheres. O feminino era um ausente, um silêncio, um esquecimento nessa tradição. Além disso, Maria Teresa Horta vai também aprender com esses autores, notadamente com Barthes, que a diferença social, que as hierarquias de classe, assim como ocorria com as de gênero, também se expressam, ganham sentido e são veiculadas e repostas através da língua, da linguagem, das palavras, dos discursos, dos textos ${ }^{6}$. Nesse livro publicado em 1967, Maria Teresa Horta vai retomar a tradição das crônicas coloniais, vai se apropriar de sua linguagem, para, no entanto, fazê-la dizer aquilo e aqueles que ela nunca tinha dito, fazê-la enunciar aquilo e aqueles que ela nunca havia enunciado: o trabalho, o sofrimento, o medo, o silêncio, a opressão, a exploração, o desterro, a emigração, o abandono, a fome, a morte dos pobres, dos camponeses, dos trabalhadores, das mulheres:

\footnotetext{
Dobrado o homem/ empresta ao campo o tempo

À água o homem/ cede/ a sua cara

O homem empresta à História/ o seu segredo

Ao rico empresta/ o camponês a vara. ${ }^{7}$
}

A versão da história nacional construída pelas crônicas coloniais, pela historiografia oficial, repetida insistentemente por outros cronistas, memorialistas e historiadores do presente, versões que serviam para sustentar 
um regime político opressor e ditatorial, que se legitimava se dizendo um continuador ou um regresso, um retorno aos tempos de glória do Portugal seiscentista, guardavam inúmeros segredos, se apoiavam, elas também, no silêncio, no esquecimento, no apagamento de outras memórias e de outras histórias possíveis. O enfrentamento político ao regime ditatorial, do qual a escritora era uma adversária, passava pelo questionamento, pelo solapamento dessa tradição discursiva, pela reescritura dessa memória, por uma nova atitude diante do saudosismo que amparava a sacralização desses escritos do passado, que os monumentalizava, que os tornava relíquias da história do país. Era preciso, diante da tradição, assumir uma postura de traição, era preciso ser infiel a essa tradição, era necessário denunciar essa tradição, ofendê-la, não cumprir com seus mandatos e mandamentos, denunciar e delatar o que nela se escondia, manifestar e revelar o que suas estruturas silenciavam e esqueciam. Escrito no mesmo ano em que Jacques Derrida publicou seu livro de estreia, Gramatologia ${ }^{8}$, onde propunha as ideias principais do que será conhecido como o desconstrucionismo, o texto de Maria Teresa Horta mostra-se antenado com seu tempo, como parte de uma formação discursiva marcada pela atenção às estruturas linguísticas e sua relação com a reprodução das estruturas sociais, das desigualdades e hierarquias no campo econômico, social, jurídico, de gênero, de etnia. A crítica da dominação de classe, assim como das hierarquias de gênero, deveria passar pela crítica do logocentrismo, de uma dada figura da racionalidade, que a associava exclusivamente ao masculino e que jogava para as margens e desqualificava os sentimentos, as paixões, inclusive a própria sensualidade, o erotismo, o corpo, associados ao universo feminino. Esse logocentrismo era estruturante dos chamados gêneros narrativos, como aqueles que se dedicavam, no presente, a reler as crônicas coloniais, textos pertencentes a uma outra ordem discursiva, onde o lendário, o mítico, o ficcional ainda não haviam se separado do que seria o memorialístico e o histórico ${ }^{9}$.

Publicado um anos antes do movimento de maio, na França, contemporâneo da chamada contracultura, dos levantes estudantis, das mobilizações pelos direitos civis dos negros, da emergência do movimento homossexual, das reinvindicações feministas, o texto de Maria Teresa Horta vem deixar patente que toda obra de arte é produto de um dado tempo, de uma dada estrutura do sensível que prevalece em um dado momento, é fruto do circular das ideias, do pensamento de um dado período, articulados a uma experiência pessoal e coletiva ${ }^{10}$. Embora costumemos ter uma imagem do Portugal salazarista como um país atrasado e fechado a toda ordem de acontecimentos inovadores e vindos do exterior, o livro de Maria Teresa Hora, assim como o próprio movimento literário do qual participou, no início da década de sessenta, deixa patente que nenhum país, que nenhuma cultura, por mais que se pretenda cerrada, avessa, reativa às influências estrangeiras, estranha aos influxos culturais vindos de outros lugares, pode impedir de que 
esses fluxos atravessem suas fronteiras, que haja conexões desterritorialzantes e desterritorializadoras dessa pretensa unidade cultural e nacional.

O primeiro embate de Maria Teresa Horta com o papel do discurso, da linguagem na reprodução da ordem vigente, se deu na plaquete intitulada Tatuagem, publicado como parte de uma revista-manifesto chamada Poesia 61, editada nesse mesmo ano na cidade do Faro, pelo poeta Casimiro de Brito, reunindo além da sua própria contribuição e a de Maria Teresa Horta, plaquetes de Fiama Hass Paes Brandão, Gastão Cruz e Luiza Neto Jorge ${ }^{11}$. Essa revista e seu título foram tomados como manifesto de uma nova maneira de fazer poesia, de lidar com a linguagem, de relacionar linguagem e mundo na poética portuguesa. A Poesia 61 se caracterizaria por uma ruptura com o movimento neo-realista que dominara a literatura e a poesia portuguesas desde o imediato pós-guerra, em que o realismo e uma preocupação de cunho social eram marcantes. O grupo da Poesia 61 serão identificados com a introdução de uma poética experimental, com o experimentalismo em Portugal, uma poesia onde mais do que o assunto, o tema, o conteúdo, há toda uma ênfase e uma preocupação com o trabalho estético, formal com a linguagem, com as palavras. Impactados por movimentos como o concretismo e o neoconcretismo brasileiros, pelo nouveau roman francês, que divergem dos gênero literários clássicos, que contestam os gêneros tradicionais, como eram as crônicas coloniais, e enfatizam o texto literário como diferença em relação a qualquer identidade literária veiculada pela tradição, privilegiando os experimentos estilísticos, a construção de linguagens singulares, a fragmentação das narrativas, a invenção de uma linguagem individual que fosse uma espécie de construção do próprio ser do autor ${ }^{12}$. Ao optar pela palavra "tatuagem" para intitular seu livro, Maria Teresa Horta vai expressar uma das marcas de seu fazer literário, pensar o corpus literário, a escritura literária, como a escritura mesma de um corpo, de seu corpo. Maria Teresa Horta vai procurar, em sua obra literária, escrever com o corpo, tal como teorizara Roland Barthes ${ }^{13}$, inscrever o corpo no texto, deixar a marca de seu corpo no que escreve, e, ao mesmo tempo, ter o seu corpo marcado, tatuado por sua escritura, ter seu corpo reescrito por seus textos. Escrita feita no momento em que as mulheres politizam seus corpos, em que o corpo feminino emerge como questão política, como descoberta, como revelação para as próprias mulheres, em que elas lutam para tomarem posse de seus corpos, por tanto tempo destinados a ser objeto de pertença, posse, controle e desejo dos homens. A libertação, a liberação feminina passava por um trabalho no campo da linguagem, mas também um trabalho sobre seus corpos, sobre o dispositivo da sexualidade ${ }^{14}$ que reservava para elas o lugar de mãe, esposa e dona de casa, recatada e pura; dispositivo sustentado e amparado numa ordem discursiva e numa hierarquia de corpos, na figuração e conceituação do corpo feminino, em saberes que o desqualificavam. Dominação masculina que passava pelo próprio apagamento do desejo 
feminino, de seu estrito controle, pois visto como perigoso, transgressivo e desregrado; passava pela domesticação dos corpos e desejos das mulheres, pela negação de sua libido, de seu erotismo, do seu direito ao prazer. Assim como a obra barthesiana, Maria Teresa Horta vai procurar inscrever o prazer no texto, ao mesmo tempo, que goza com o prazer do texto. Gozar com as palavras e gozar através das palavras uma maneira de afirmar o desejo feminino, de fazer emergir seus corpos, por tanto tempo apagados da História:

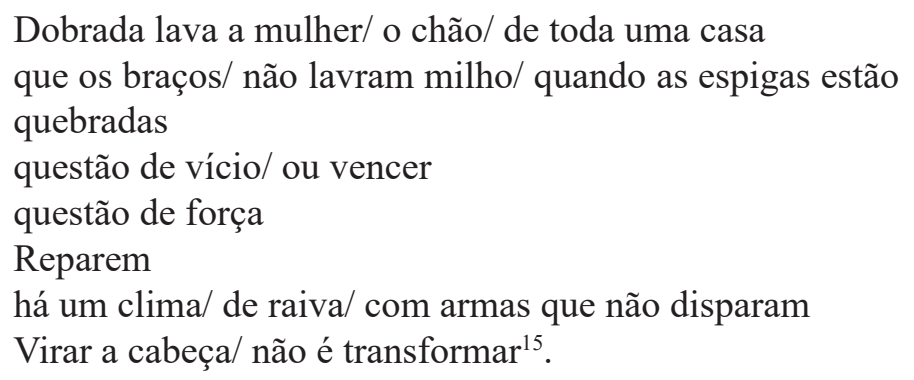

A raiva, a revolta da autora, se expressa através de uma arma que não dispara: a poesia, os textos que escreve. Ao contrário das glórias masculinas contadas pela história nacional, pelos cronistas, apoiadas em armas e batalhas, representadas nos museus por espadas e escudos, cheias de heroísmos guerreiros, a história das mulheres se fez no trabalho diário, rotineiro, pesado, obscuro, na faina da vida doméstica, o que incluía fazer as mesmas tarefas do marido, mas ser vista e dita apenas como ajudante e, muitas vezes, cuidar de suas feridas, de seus aleijões, ou fazer o seu enterro, após suas fainas militares. Portugal foi um país em que, desde longa data, coube às mulheres substituir na vida cotidiana seus maridos e filhos, que partiam para suas aventuras marítimas, em busca do peixe ou de novas terras, na busca de riquezas, glórias ou apenas na busca por sobrevier. Coube a elas o fiar de narrativas da saudade, de fazer da saudade cotidiano e conto, de expressar suas saudades com lágrimas e cantos, coube a elas ficar na terra e esperar. Ela, a poeta, não vira a cabeça para essa tradição, para essa saudade, saudade e tradição que não estavam inscritas, tatuadas nos textos, escritas nas crônicas, mas que ficaram tatuadas na pele, grudadas no corpo das mulheres de sua terra, que circularam e sobreviveram nas vozes, nos cantos, nos lamentos de suas conterrâneas. Como se vestidos fossem, essas saudades, essas tradições aderiram aos corpos, se fizeram um só corpo, se encarnaram na carne das mulheres, em seus desejos não realizados, nas suas convivências com os corpos ausentes, com os corpos fantasmáticos de seus amados. Elas eram como materializações das noites de insônia de corpos afogueados pela libido, corpos a se remexerem nas camas e catres aguilhoados pela tormenta de quererem quem ali não está. Essas histórias as crônicas não contam, a história não registra, esses tormentos não produzem heróis, essas batalhas não geram comendas, nem comemorações: "Rainhas mortas na cama/ 
de partos/ não fazem História, nem factos"16.

Se defrontar com essa tradição, enfrentá-la criticamente, era um exercício de confrontação não apenas em relação à condição coletiva das mulheres na sociedade portuguesa de então, mas era também fazer um difícil acerto de contas com o próprio passado de sua família, com o seu próprio passado de descendente, pelo lado materno, de uma família aristocrática e pelo lado paterno, de uma família burguesa. Nascida em 20 de maio de 1937, já portanto quando da vigência do chamado Estado Novo, Maria Teresa Mascarenhas Horta era filha de João Augusto da Silva Horta, um profissional liberal, graduado em medicina pela Universidade de Lisboa, onde veio a se tornar professor catedrático e diretor da Faculdade de Medicina, com tese de doutorado defendida na área da anatomia patológica, em 1940, que obteve sucesso e reconhecimento profissional, dedicando-se à questão da transfusão e doação de sangue em Portugal, tendo assumido entre 1956 e 1962 a direção da Ordem dos Médicos, sendo o quinto bastonário dessa instituição que, como vemos, mesmo sendo uma instituição ligada a uma profissão liberal, adota ares aristocráticos ao assumir o conceito de Ordem e dar a seus diretores o título de bastonários. Sua mãe, Carlota Maria Mascarenhas era neta, por bastardia, de José Maria Mascarenhas, o nono marquês de Fronteira, o décimo conde da Torre, o sétimo marquês de Alorna e o décimo primeiro Conde de Assumar ${ }^{17}$. O título de Marquês da Fronteira foi atribuído por carta, por D. Afonso VI, em 07 de janeiro de 1670, a D. João de Mascarenhas, segundo conde da Torre, por seus feitos militares na Guerra da Restauração (1640-1668), contra a Espanha ${ }^{18}$. Maria Teresa Horta fazia parte, assim, de uma antiga linhagem aristocrática que, ainda após a proclamação da República, em 1910, continuou sendo preservada, ocupando o lisboeta Palácio dos Marqueses da Fronteira, palácio de estilo renascentista inaugurado em 1675, pelo primeiro marquês da Fronteira, hoje considerado monumento histórico nacional. Se a vida e a obra de Maria Teresa Horta, se o livro Cronista não é recado, são um acerto de contas com as narrativas genealógicas e nobiliárquicas, com as memórias familiares e aristocráticas, que constituíam a tradição de uma dada história aristocrática e da nobreza, fundada numa saudade do período monárquico, do fausto que no passado caracterizara a vida de uma classe agora decadente, ela, no entanto, não constitui uma exceção. Uma das descobertas que a pesquisa sobre a temática da saudade em Portugal proporcionou foi o expressivo número de descentes da antiga nobreza que adotam posições políticas de esquerda, no decorrer do século XX. O declínio econômico e político trazidos pela emergência e desenvolvimento da sociedade capitalista, pelo domínio social e político da burguesia, a reação, muitas vezes eivada de romantismos, em relação ao mundo moderno, à sociedade do trabalho, da técnica, da indústria, à cultura e sensibilidades burguesas vistas como abastardadas e filistinas, afetadas, antinaturais, a reação às formas e costumes políticos da república e da 
democracia liberal, levam a que muitos filhos de aristocratas, educados numa espécie de mundos paralelos - no interior das casas recebendo uma educação ainda nos moldes aristocráticos e na rua, na escola, recebendo uma educação burguesa -, recusassem em bloco essas duas tradições, e a que se solidarizassem com os oprimidos, com os trabalhadores, com os camponeses, com aqueles que agora pareciam estar ainda em pior condição do que quando podiam contar com os códigos paternalistas que regiam as relações entre senhores e seus serviçais:

Levam os feitos para a/ História/ reis de tronos cinzelados Para quem é malfadado/ não há brocado/ nem fato Cronistas dizem das naus/ mas não dizem do arado/ que lavra a História do povo/ feita de povo descalço.

A História que tem a/ espada/ para fazer o seu pão/ só utiliza a enxada

Dossel bem torneado/ a dama aguarda de linho A mulher que vai descalça/ tem um filho no caminho

A História conduz/ o povo/ gente de saio encarnado Levam os feitos/ cinzel/ cronista não é recado Que recado do homem/ não sai de quem malfadado. ${ }^{19}$

Na própria família de Maria Teresa Horta essa posição não foi isolada. Seu primo, D. Fernando José Fernandes Costa Mascarenhas, o décimo segundo marquês da Fronteira, nascido em 17 de abril de 1945, portanto, oito anos mais novo que sua prima, foi um opositor do Estado Novo, abrigou reuniões clandestinas da oposição em seu palácio no Benfica, desde o início dos anos sessenta. Em uma delas, em que a oposição democrática visava traçar estratégias para as eleições de 1969, teve seu palácio invadido pela PIDE, a polícia política. Fazia questão de se nomear de esquerda, era conhecido como o "marquês vermelho", sua atuação chegou a ter repercussão internacional: o jornal francês L'Express certa vez publicou como blague que em Portugal estaria surgindo mais uma corrente de esquerda: o marquesismo-leninismo ${ }^{20}$. Portanto, nesses anos sessenta Maria Teresa Horta não estava sozinha, em sua família, em seu distanciamento do regime e da chamada tradição a que se referia para se legitimar: essa tradição aristocrática que, também em seu primo, vai se expressar através de uma atenção especial a ações culturais e educacionais para a população. É também em sua família materna, em seu passado aristocrático que Maria Teresa Horta vai buscar um exemplo, um modelo de ser mulher, de ser feminino a partir do qual pensa e constrói a si mesma, como pessoa e como artista. A narrativa da vida de uma de suas antepassadas, tantas vezes ouvida dos lábios de sua mãe, uma mulher que teria rompido com os limites impostos para a vida das mulheres de sua época, que, 
como ela, se tornara uma poeta reconhecida e admirada, serviu como exemplo de uma outra tradição narrativa, de uma outra história, de uma outra memória, pouco escrita, ausente dos manuais de história pátria, não figurando na história oficial do país, sustentada pela oralidade, repassada pelas várias gerações de mulheres que se sucederam em sua família. A poeta Alcipe, Leonor Almeida Portugal de Lorena e Lencastre, nona condessa de Assumar e quarta marquesa de Alorna, dama de honra de D. Carlota Joaquina, da infanta D. Isabel Maria de Bragança e da rainha D. Maria II de Portugal, vai merecer posteriormente, por parte de Maria Teresa Horta, uma longa pesquisa histórica e documental, que servirá de base para a escrita da biografia romanceada As Luzes de Leonor, publicada em $2011^{21}$. Filha do Iluminismo, da revolução, do liberalismo, do racionalismo, mas também do romantismo, Leonor encarna para Maria Teresa Horta uma outra tradição, minoritária na sociedade portuguesa, encharcada de catolicismo, de carolice religiosa, de irracionalismo místico e milenarista, de saudosismo estamental e antirrepublicano, um país fascinado pelas sombras, pelo nevoeiro, pelas trevas, pelo negror, inclusive nas vestes femininas, onde as Luzes têm pouco lugar.

Mas ao convocar essa memória de família, ao convocar a figura de sua antepassada, não há qualquer traço romântico, de desejo de regresso ou de retorno no tempo por parte da escrita e da ação de Maria Teresa Horta. Com ela podemos aprender que, nem sempre, saudade quer dizer regresso, nem sempre saudade quer dizer conservação, retorno, manutenção de um dado passado visto como ideal, nem sempre a saudade é lembrança com desejo de retorno, tal como a definiu o poeta Teixeira de Pascoaes ${ }^{22}$. O passado pode ser tomado como o ponto de partida para a construção de um outro presente e de um outro futuro, pensados como diferença, como ruptura, como descontinuidade em relação ao tempo que foi e em relação ao tempo do agora. O passado, as narrativas que configuram dados eventos, dados personagens, dados tempos idos, devem apenas servir de pretexto, de textos prévios a partir dos quais novas narrativas, novas elaborações, novas reescrituras serão feitas para esses sujeitos, fatos e épocas. As saudades de Leonor são um recurso estético e político para introduzir, no presente, a discussão sobre a condição das mulheres em Portugal. Tomar a vida, as luzes de Leonor para tentar iluminar a distância e a proximidade entre as condições de vida das mulheres portuguesas no oitocentos e no século XX. O mesmo fará quando, em 1972, juntamente com Maria Isabel Barreno e Maria Velho da Costa, recorre à lendária figura da freira Mariana Alcoforado, para ser a personagem principal do livro Novas Cartas Portuguesas, publicado em 1972. Mariana Alcoforado, esse personagem feminino que deu origem a toda uma tradição narrativa e lendária seria uma freira que, no século XVII, pretensamente escrevera, no convento de Beja, cinco cartas endereçadas ao seu amante, o Cavaleiro de Chamilly, Noel Bouton, tornando-se célebre, pelo caráter transgressivo e escandaloso, para a época, de uma escrita feminina 
que falava do corpo, do desejo, do sexo, do amor em sua carnalidade e não apenas em sua dimensão espiritual, quando essas cartas aparecem publicadas em francês, em 1669, como obra anônima, intitulada Lettres Portugaises, pelo editor Claude Barbin, de Paris ${ }^{23}$. Esse personagem da tradição literária e cultural portuguesas vai ser agenciada pelas três escritoras feministas para denunciar o que seria a continuidade da condição subalterna das mulheres em Portugal, mas ao mesmo tempo, para relançar no presente o que essa vida e os escritos que produziu tiveram de desruptores, de contestadores para sua época. Assim como as luzes de Leonor, o erotismo feminino das Cartas portuguesas de Mariana Alcoforado é uma outra tradição, é uma tradição minoritária, é uma traição à tradição pensada, vista e escrita no masculino. A ida ao passado aqui, a saudade aqui não vem carregada de desejo de continuidade e conservação, a saudade aqui é uma estratégia estética e política a serviço da mudança, da transformação da condição feminina em Portugal. As vidas passadas, essas mulheres do passado são revistas e reescritas para que a transgressão e a ruptura que significaram possam novamente fazer efeito no tempo presente. Voltar a elas não quer dizer regresso, mas ao reverso, quer dizer a abertura de futuros outros, de devires que apontem para outros lugares para o feminino.

Nos valendo das reflexões de Walter Benjamin ${ }^{24}$, podemos dizer que o gesto poético e político de Maria Teresa Horta em seu livro Cronista não é recado, é aquele presidido pela produção de imagens que nascem do choque dialético entre o passado e o presente, em que as imagens do passado não são apenas repetidas, mas colocadas em tensão com imagens de outros tempos e de outras realidades. A poética estilhaçada da poetisa portuguesa parece remeter ao procedimento que no início do século XX, sob a influência do surrealismo - que também se faz presente no experimentalismo português do início dos anos sessenta -, foi utilizado pelo crítico de arte Aby Warburg, o procedimento da montagem dialética, que remetia, também ao trabalho do cineasta soviético Sergei Eisenstein ${ }^{25}$. Colocar lado a lado imagens antitéticas, imagens retiradas de contextos históricos e sociais diversos, para produzir pelo encontro, pelo choque a revelação, o desrecalcamento de sentidos esquecidos ou censurados. As imagens do passado, as imagens sobreviventes, para se referir a uma noção presente em Georges Didi-Huberman, como aquelas presentes nas crônicas coloniais, como aquelas que remetiam ou se referiam a mulheres de linhagem aristocrática que puderam, em algum momento escrever, dizer de si, tomar a palavra, assumir voz própria, falar de seus desejos, sonhos, de suas paixões, de seus sofrimentos e de suas maneiras de pensar e ver o mundo, servem de material, de arquivo para a construção, na linguagem, de outros corpos, de outras figuras, de outros desejos, de outras versões do feminino, ao serem tomadas como sintomas do que foi silenciado, apagado, esquecido, recalcado no que tange a história das mulheres. É como se ao explodir a urdidura desses discursos, ao desfiar as suas tramas, ao estilhaçar os seus enredos, sobrassem, 
deles, fragmentos, imagens soltas, estilhaços enunciativos, concisas figuras, fulgurações que permitem construir outras configurações, outros perfis, outros desenhos, outras narrativas para esses tempos e personagens, como também para o tempo e personagens do presente:

Senhora tece no linho/ sentada no seu escabelo trata-lhe a aia/ o cabelo borda no corpo/ o vestido

Senhora no seu castelo/ à espera de seu marido veste-lhe a aia/ o vestido a cama sem seu/marido Senhora que tem no fuso/ o ócio das suas mãos a ama trata-lhe/ o filho a aia do seu/ cabelo o linho/ do seu vestido ${ }^{26}$

\section{A saudade como invenção}

O questionamento que o livro Cronista não é recado faz do papel da escrita na construção de versões sobre o passado, na elaboração da historiografia, explicitando o caráter estético, mas também político dessas narrativas, sua crítica contundente a uma dada mitologia saudosista que, apoiada em dadas versões do passado português, servia de discurso de legitimação do regime salazarista, que vivia dias difíceis com a doença de Antônio Salazar e a necessidade de encontrar alguém para substituí-lo, chama a atenção do regime sobre a figura de Maria Teresa Horta, que começa a gerar desconfiança. Essa percepção do papel da linguagem no ofício do historiador vai anteceder a própria discussão dessa questão pelos próprios historiadores, que só se dará a partir do início da década de setenta. A crítica ao saudosismo na cultura portuguesa, que mostra ser uma atitude estética mas com inegáveis dimensões políticas, vai anteceder, em dois anos, a gravação da música Saudosismo ${ }^{27}$, composta por Caetano Veloso, gravada por Gal Costa, em 1969, que também estabelece uma clara correlação entre a adesão de parcelas da sociedade brasileira a valores e concepções de mundo conservadoras e tradicionalistas e o apoio que esses setores davam à ditadura militar, tal como Maria Teresa Horta fazia para o caso português. Esses códigos de valores tradicionais sustentavam, como deixa explícito o trabalho da poetisa portuguesa, o lugar de subalternidade das mulheres, a censura moral a que eram submetidas, sua desqualificação social e profissional, o machismo e a misoginia presentes na sociedade e cultura do país. Como diz o filósofo Michel Onfray: "O que é um momento dado, se encontra também em cada um de seus fragmentos disseminados"28. É a essa espécie de clima, de estilo de uma época, que se manifesta em diferentes atividades, que faz emergir pensamentos, ideias, práticas, obras, autores que se conectam sem 
que se conheçam ou que conheçam o que cada um está fazendo que podemos nomear de sensibilidade de uma época, aquilo que Alain Corbin nomeou de estruturas do sensível, presentes em dado momento ${ }^{29}$.

Um ano após a publicação de Cronista não é recado, Maria Teresa Horta passa a ter uma presença pública ainda mais destacada, a medida em que passa a se dedicar profissionalmente ao jornalismo. Embora já tivesse escrito contribuições esporádicas para os jornais A República e Diário de Lisboa, jornais que adotavam uma postura de defesa da república e da democracia, vai se engajar no projeto de criação do vespertino $A$ Capital, a convite do jornalista Mário Neves. Além de ser um jornal de oposição ao regime, A Capital se notabilizará, justamente, por abrir espaço para uma crescente presença feminina no jornalismo. Ela se torna responsável pelo suplemento Literatura e Arte, mas tem que lidar ainda com a desconfiança e certo receio dos colegas homens. As salas das jornalistas ficavam separadas da grande sala de redação do jornal, onde imperavam os homens, a pretexto de protegê-las contra o mal comportamento destes e o uso constante de palavrões. A mesma lógica de hierarquização e separação por sexos que imperava no discurso pedagógico e político, se materializava nas práticas cotidianas, da divisão e hierarquização dos espaços e das funções nas redações de jornais ${ }^{30}$. Ela era casada com o também jornalista Luís Barros - a quem oferece todos os seus livros de poesia e para quem faz grande parte de seus poemas eróticos -, discutindo com ele não somente sobre a situação política do país mas a própria condição feminina.

Mas será com a publicação do seu livro de poemas Minha Senhora de Mim, em 1971, que ganhará notoriedade. Desde o título o livro significa a afirmação de um feminino que é senhor de si mesmo, que não se subordina ou se submete. Um feminino que assume o controle da palavra, que se torna sujeito de um discurso erótico, que assume, assim, um lugar de sujeito tradicionalmente ocupado pelo masculino. Uma voz feminina a falar de seus desejos, de seu corpo, de seus prazeres, de seus deleites. Uma figura feminina que assume o controle, inclusive, no momento do ato sexual, que assume a direção de seu corpo e de seus prazeres, que guia o seu amante na exploração e penetração de seu corpo. Uma escrita feminina que, assim como a escrita de Marguerite Duras, citada na epígrafe do livro, e de Clarice Lispector, se interroga pelo ser mesmo do feminino, pela possibilidade de dizê-lo numa linguagem que é masculina. Uma escrita que parece buscar ao rés do corpo, num retorno ao corpo próprio, ao corpo feminino, esse corpo misterioso, cheio de segredo para as próprias mulheres, corpo que nunca lhes pertenceu, a verdade do ser feminino. Na palavra, no poema a busca por uma essência feminina que só faz se ausentar, um ser que, quanto mais se escava na linguagem, mais aparece como vazio, como falta, no mesmo momento que aparece como invenção da própria linguagem. $\mathrm{O}$ feminino como performance de gênero que se passa na vida, que se materializa no corpo e na linguagem: 
Senhora minha/ raiz/ resguardada no seu jeito

Dama vestida de mim

Fechada nos seus poemas/ a fiar o meu enjeite ${ }^{31}$

Nesse livro, assim como no anterior, Maria Teresa Horta parte de um gênero poético considerado tradicional e nacional, para transgredi-lo, para reinventá-lo, para recriá-lo. Mais uma vez, aqui, a saudade não é regresso, o uso do passado se faz em nome de sua reescritura criativa. A forma identificada como tradicional é utilizada para tratar de temas, para veicular um conteúdo contemporâneo, para tratar de problemas, de questões do presente. A forma dita tradicional é atraída para outras derivas e traída mediante procedimentos que vão paulatinamente a desfigurando, a aproximando de formas contemporâneas, estabelecendo ligações surpreendentes entre os tempos, constelando imagens de distintas temporalidades. Ela parte de um dos gêneros poéticos presentes no trovadorismo português: as cantigas de amigo. Esse gênero apresentava a particularidade de que nele o trovador assumia um eu lírico feminino - daí ter interessado a Maria Teresa Horta -, ele cantava o ponto de vista do outro lado da relação amorosa, de uma mulher, quase sempre humilde e ingênua, que canta o desgosto de amar e depois ser abandonada; ou uma mulher que se apaixonou e que dirige um lamento à natureza, a si mesma ou a outrem, no qual fala de seu ideal amoroso e das tristezas de não poder ver o ser amado, sempre distante, impossível, presentificado mediante o canto de sua saudade. Ela canta seu amor pelo amigo sempre ausente, por recusa ou impedimento da relação, canta as alegrias dos encontros, e a tristeza das ausências, a incerteza de ser amada. Proveniente da tradição oral dos trovadores e jograis, as cantigas de amigo possuem uma estrutura poética destinada à fácil memorização, estando marcada pela constante repetição dos elementos do poema, notadamente do refrão e do estribilho, sustentando-se em paralelismos e reiterações ${ }^{32}$.

Mas como já enuncia o poema que abre o livro, intitulado "Regresso"33, esse retorno ao passado, essa retomada de um gênero poético da tradição, essa ida ao arquivo da cultura portuguesa, não está marcado pela mesma saudade que se encontrava no canto de queixume e lamúria do eu lírico feminino das canções de amigo. Esse regresso não é encontro, é desencontro, ele busca aproveitar essa tradição poética que abre espaço para a expressão de um eu lírico feminino, mesmo sendo cantado por homens, para que uma mulher, poeta, agora possa se expressar. Se no passado era o jogral que se deslocava e se colocava em outro lugar de sujeito, num jogo de linguagem em que assumia a voz feminina, para veicular uma dada imagem das mulheres, de seus amores, de suas paixões, agora é a poeta que assume o lugar do jogral, que destrona o masculino de seu lugar de fala e passa ela mesma a falar do feminino, portanto, sendo uma fala não apenas no feminino, mas do feminino. Não possuindo uma linguagem própria, não dispondo de uma língua e de gêneros narrativos que não sejam 
expressões do masculino, cabe às mulheres se apropriar desses lugares de fala, cabe às mulheres saquear os gêneros narrativos, pilhar a língua e a linguagem, se insinuar e se imiscuir nas entranhas dos discursos masculinos para fazê-los errar, implodir, restando deles fragmentos utilizáveis pelas mulheres. Cabe às mulheres piratear a língua, se apossar dos gêneros para submetê-los a operações de torsão e transgressão: só assim poderão expressar o seu gênero. $\mathrm{O}$ encontro com as cantigas de amigo, onde pretensamente as mulheres falavam de si, no entanto, é o encontro com uma ausência, é o encontro com um feminino imaginado, dito, visto pelo masculino, é um retorno onde não há encontro, mas desencontro. Com a tradição poética, assim como com a tradição memorialística e historiográfica, as mulheres só podem se desencontrar, só podem operar com a traição, figura atávica do feminino, medo ancestral do masculino:

Regresso para $\mathrm{mim} /$ e de $\mathrm{mim}$ falo/ e desdigo de $\mathrm{mim} / \mathrm{em}$ reencontro

Trago para fora/ o que é secreto/ vantagem de saudade/ o que é segredo

Retorno para $\mathrm{mim} / \mathrm{e}$ em mim toda/ desencontro já o meu regresso $^{34}$

Em Senhora de mim, de Maria Teresa Horta, a saudade não traz de volta o conhecido, não traz de volta o amigo, não traz de volta uma figura de mulher prescritiva e convencional, não convoca o canto de um amor espiritualizado, idealizado, não evoca um ser amado incorpóreo, fantasmático, deserotizado, não convoca um canto de queixume e de lamento, figurando um ser feminino frágil, puro, inocente e lacrimoso. Antinomicamente a saudade aqui traz para fora o que é secreto, o que é segredo, serve para tratar de aspectos comumente ignorados, silenciados do ser feminino, serve para figurar um ser feminino que se afasta da mulher da poesia trovadoresca e do amor cortês. A saudade serve aqui também para nomear uma ausência, para convocar um ser ausente, mas a ausência não de uma figura, de uma presença outrora existente, mas de uma figura nunca existente, o não do ser, aquela que existiria apenas como o outro denegado do discurso masculino: a mulher. Todo regresso, toda saudade é desencontro para as mulheres, porque elas nunca se encontram onde estão nomeadas e assinaladas no discurso masculino. Como encontrar com o feminino num discurso como o das cantigas de amigo, onde a mulher é incorporada, vista e dita por um corpo, por um ser masculino? Por isso, qualquer mergulho no arquivo, qualquer imersão na tradição em busca do feminino o encontrará como desencontro, o encontrará como saudade do segredo, do secreto, do silêncio.

Como explicitamente vai afirmar no poema "Cantiga sobre o lamento", a saudade, nesse livro, é um disfarce, é uma estratégia discursiva e política. 
Ela se enfeita de saudade, ela veste a saudade para dar a ela outros sentidos, ela se mascara com o discurso, com a temática, com o gênero narrativo que remete à tradição, ao passado, ela se traveste de saudade, para questionar de seu interior as imagens do feminino, os lugares e hierarquias a que estaria destinado. Sorrateiramente se apossa de uma tradição em que o masculino se travestia de feminino, para ocupar o lugar de fala que seria dos homens e, assim, poder dizer de coisas sobre as mulheres que só eram permitidas aos homens. Seu lamento é apenas ornamento, sua saudade reside apenas na forma que toma da tradição, a cantiga de amigo é apenas uma casa que a recepciona para aí fazer a sua construção poética própria:

Lamento: minha amizade/minhas trevas/ e deserto Meu enfeite de saudade/ meu disfarce/ de ilusão Lamento: meu ornamento/ minha casa em construção ${ }^{35}$

O grande escândalo que o livro causou, os dissabores políticos e pessoais que ocasionou mostram que sua estratégia discursiva e política foi efetiva. $\mathrm{O}$ fato de uma mulher falar do corpo, do prazer, do desejo, do erotismo, do ato sexual, da dimensão carnal do amor, numa sociedade portuguesa de valores morais católicos, muito conservadores, vivendo sob um regime ditatorial, misógino e machista, um regime militarizado e masculino, de homens velhos e senis, um ano depois da morte do ditador e da ascensão ao poder de Marcello Caetano, a tornou o centro de um grande acontecimento político e social. Além da recepção violenta da crítica, ela passou a receber cartas anônimas e telefonemas ameaçadores, tanto de homens, quanto de mulheres: bilhetinhos com propostas para encontros amorosos e sexuais eram deixados em sua porta, recebendo a censura de amigos e parentes, que passaram a evitá-la. Uma noite, chegando em casa, acompanhada do marido, vê-lo ser imobilizado e, atirada ao chão, é violentamente espancada por três agentes da PIDE, a polícia política, que a xinga com palavras de baixo calão e avisam que a surra era para ela não continuar escrevendo como escrevia. No dia 03 de junho de 1971, menos de dois meses após a publicação da obra, sob as ordens da Diretoria Geral de Segurança, a PIDE invade a editora Dom Quixote e recolhe toda a edição do livro através de um auto de busca e apreensão. A proprietária da editora (e só uma mulher teria coragem de publicar o livro, como atesta Maria Teresa Horta) Snu Abecassis é advertida de que teria sua editora fechada caso voltasse a publicar qualquer outra obra de Maria Teresa Horta ${ }^{36}$. Esse episódio mostra o quanto era transgressivo o seu discurso, a inseparável relação que havia entre a manutenção da ordem política vigente e uma dada ordem familiar, uma dada cultural moral, dadas hierarquias entre os gêneros. Toda ditadura teme os intelectuais por sua capacidade de criação, análise e crítica, ainda mais intelectuais mulheres, numa sociedade como a portuguesa do início dos anos setenta do século passado, onde as mulheres ainda não haviam conquistado 
importantes espaços na sociedade. Seus versos foram considerados impróprios para figurarem numa voz feminina, sua poesia foi considerada pornográfica e sua pessoa confundida com a persona poética que assumiu em seu livro. Sua saudade não é da mulher etérea, idealizada das canções de amigo, sua saudade é da mulher carnal, erótica, da fêmea que se entrega na cama. Sua saudade é do amigo que lhe acaricia os seios, lhe lambe a vagina, penetra seu corpo com vigor e a faz gozar. Sua saudade é dos instantes fugidios e que, ao mesmo tempo, parecem eternos, parecem prolongar o tempo, congelá-lo, em que se entrega ao ser amado. Tanto o ser feminino como o amigo aqui são corpóreos, são carnais, não cantam a ausência, cantam os fugazes momentos de presença intensa, intensiva. Sua saudade é da língua que retira prazer de sua ferida, de sua fenda, que bebe de sua taça, de seu copo, de seu sumo. Mas sua saudade é também da língua, de uma língua que pudesse dizer o prazer feminino, que pudesse expressar suas feridas, as dores e sabores do ser feminino:

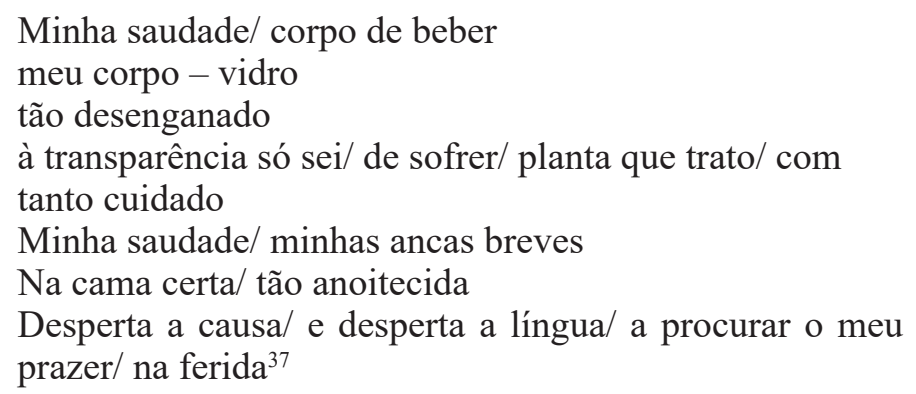

Assim como na tradição trovadoresca trata-se de procurar o prazer no texto, de procurar o prazer na ferida, mas não só neles. A mulher deve lutar pelo direito ao prazer na vida. Esse enunciado era um dos mais contemporâneos e transgressores advindos do discurso feminista. A partir dos episódios que seu livro desencadeou, Maria Teresa Horta resolve assumir publicamente o lugar de militante feminista. Leitora de Reich, de Marcuse e de Bataille, Maria Teresa Horta assume em sua obra o caráter liberador do erotismo. A libertação das mulheres passaria pela liberação da palavra, do desejo, da fala de desejo feminina. Não poderia haver liberação feminina sem que o feminino pudesse assumir com liberdade a palavra, inclusive para falar de temas ditos masculinos, como era inclusive os temas políticos. Em resposta ao que sofreu com a publicação do livro Senhora de mim, se alia a duas outras escritoras, Maria Isabel Barreno e Maria Velho da Costa, constituindo o que viria a ser conhecido até internacionalmente como as "três Marias", e resolvem escrever um livro-manifesto, um livro a três mãos, onde ninguém saberia quem teria escrito o quê (até para se resguardarem das consequências políticas, policiais e jurídicas que daí pudessem advir), que se chamaria Novas Cartas Portuguesas, já que mais uma vez tomavam a tradição narrativa existente, uma narrativa 
epistolar, pretensamente feminina, escrita por um freira de Beja, que teria vivido e tido um amante francês, no século XVII, como pré-texto, como texto prévio, a partir do qual criariam seus próprios textos, em que uma voz feminina vem dizer de seus desejos, de suas dores, de seus sofrimentos, vem expor a condição das mulheres em Portugal. Ao recorrerem a imagens que, pretensamente, seriam do passado, as autoras questionam duramente a situação das mulheres na sociedade portuguesa de então, o passado servindo de ponto de partida para uma leitura do presente e para abrir possibilidades de futuro. Publicada em 1972, a obra é imediatamente recolhida de todas as livrarias, considerada imoral, as três autoras são presas, acusadas de atentado à moral e aos bons costumes. Para surpresa do regime, o caso ultrapassa a fronteira do país, sendo denunciado por feministas de vários países. Várias manifestações são promovidas em prol da libertação das três escritoras. Em Paris, uma grande marcha de militantes feministas, encabeçada por nada menos que Simone de Beauvoir, percorre as ruas portando faixas e cartazes que denunciavam o regime político português e pediam a imediata libertação das três autoras. O processo só é concluído com a absolvição das escritoras após o fim do regime, em 1974, com a Revolução dos Cravos, para a qual muito concorreu o desgaste internacional sofrido pelo governo Marcello Caetano que pretendia se legitimar como um governo liberalizante e distinto ao de Salazar, sendo completamente desmentido com esse episódio ${ }^{38}$ :

$$
\begin{aligned}
& \text { É corpo para/ ofertar/ no lençol sem abrigo } \\
& \text { a seu amigo } \\
& \text { É corpo-alva/ de amar/ no lençol sem abrigo } \\
& \text { a seu amigo } \\
& \text { É corpo justo/ ao desejo/ no lençol sem abrigo } \\
& \text { a seu amigo }{ }^{39}
\end{aligned}
$$

\section{Saudades do feminino}

O pensamento feminista terá uma grande importância na vida e na obra de Maria Teresa Horta, na interrogação constante que sua poesia fará sobre o ser feminino, sobre as relações com o masculino e, principalmente, na reflexão sobre o desejo, sobre o prazer, sobre o erotismo feminino, na colocação do corpo e da sexualidade como o ponto de partida para a elaboração de uma plataforma de liberação das mulheres. Maria Teresa Horta toma o trabalho poético como um campo de luta pela emancipação da escrita feminina de dadas tradições narrativas, da prevalência do masculino na própria linguagem, daí a importância do experimentalismo e da traição a essas tradições. Para ter um lugar efetivo no mundo as mulheres necessitavam tomar a palavra, encontrar uma linguagem própria, uma maneira de dizer específica, era preciso transgredir não apenas 
dizendo aquilo que era proibido às mulheres dizer, mas também dizer de uma maneira própria, específica, escavando na língua lugares próprios para habitar, para simular formas de ser feminino. A presença do pensamento de Simone de Beauvoir e do existencialismo marcam essa reflexão sobre o ser feminino, um ser que se afirma e se libera no mundo, no agir, no engajamento. Desde o seu livro de estreia, Espelho Inicial, de 1960, o uso da imagem do espelho já indicia que sua poesia é essa busca da construção de uma imagem de si, de uma imagem que é ao mesmo tempo individual e coletiva, por ser uma imagem de mulher, da mulher ${ }^{40}$. Mas, como nos lembra Michel Foucault, o espelho é um espaço heterotópico ${ }^{41}$, quem nele se mira aparece como ausência, o corpo se ausenta do lugar onde se encontra para aparecer habitando um lugar onde não está, espécie de miragem que produz um duplo do si mesmo que passa a não estar precisamente em lugar nenhum, habitando uma espécie de limbo, um espaço ambíguo, liminar, fronteiriço entre o ser e o não-ser, entre a presença e a ausência, entre o encontro e o desencontro: essas serão imagens recorrentes do ser feminino elaborado por Maria Teresa Horta. Um feminino que se busca, que se deseja encontrar, que se deseja definir, dar uma identidade, mas que escapa ali mesmo no corpo que é a sua materialidade, que deveria ser a essência de seu ser mesmo, mas o corpo é, no entanto, também o lugar do desejo, do erotismo que o faz perder seus limites e contornos claros, o desejo dá lugar a uma voragem do ser, a uma perdição de si, a uma abertura do próprio corpo para o outro, a uma ameaça de fusão que, ao mesmo tempo, é a perdição de si. Corpo feminino, esse corpo ferido, fendido, esse corpo que sangra, que se abre para um fora, que ameaça mensalmente se esvair, que se abre ao delírio e ao transe na hora do gozo. Mulher que além de se dizer na linguagem do outro, de ser, como diria Lacan ${ }^{42}$, a falta, a elaboração no discurso do outro, onde se encontrava e se ausentava, também só se encontrava no corpo do outro, na diferença do corpo do outro, no mesmo corpo em que se perdia. Como ela mesma vai dizer, ela seria o oposto da imagem clássica das feministas justamente porque toda a sua poesia vai dar conta de como ama e depende do ser amado, como é dependente do prazer que o corpo de seu homem lhe proporciona, como o ser feminino que racionalmente e politicamente elabora, que discursivamente cria para si, se perde, se abandona ao cair nos braços de seu homem, a quem deseja e, portanto, de quem depende para viver e ser feliz. A luta permanente entre a razão e a paixão, a racionalidade e o desejo, a consciência e o inconsciente atravessa a vida e a obra de Maria Teresa Horta, a feminista que nunca deixou de ser a boa esposa, a dona-de-casa, acima de tudo a apaixonada e fiel amante de seu marido ${ }^{43}$.

No entanto ela não deixa de assumir a tarefa política de levar a mensagem de liberação para as outras mulheres. Para isso, após o 25 de abril, no ano de 1978, idealizou juntamente com Alda Nogueira (militante comunista que era membro da Comitê Central do partido na clandestinidade desde 1957, tendo 
amargado nove anos de prisão durante a ditadura) a revista Mulheres, da qual assume a chefia de redação, após colaborar entre 1974 e 1978 com a página cultural do jornal Diário, uma publicação do Partido Comunista Português, ao qual estava filiada desde que ele, com o fim da ditadura salazarista, saíra da clandestinidade e fora legalizado. Nesse período anterior também colaborou com a redação de artigos esparsos para o jornal Expresso e para a coluna "Livros, Autores, Leituras" da revista Flama. Mais uma vez faz-se um uso paródico e irônico da tradição, à medida que a revista pretensamente seria uma retomada da revista Mulher, Modas e Bordados, criada em 1912 (com o título Modas e Bordados) e extinta no ano anterior, 1977, em consequência do fechamento do jornal simpático ao regime anterior, $O$ Século, que a publicava. Maria Teresa Horta e Alda Nogueira se colocam como continuadoras do trabalho de Maria Lamas, que fora editora da revista recém fechada entre os anos de 1928 e 1947, para, no entanto, fazer um trabalho completamente diferente do que fazia a antiga editora ${ }^{44}$. Uma revista feminista que se pretendia continuadora de uma outra que destinava-se a educar as mulheres para as prendas domésticas, para seu papel de rainha do lar é, evidentemente, uma atitude paródica e crítica, é uma traição à tradição. A forma do passado é retomada para infundir-lhe novos conteúdos, fazendo a forma aparecer na sua pertença a um outro universo de significação e explicitar os seus sentidos políticos, deixar claro que não havia nenhuma inocência numa revista dedicada a modas e bordados, que nela se veiculava dadas visões, dados perfis, dados valores destinados à construção social e cultural dos femininos. Em sua aparente futilidade essa revista emitia, desde o título, um discurso que destinava-se a produzir subjetividades, prescrições e ordenamentos para serem subjetivados pelas mulheres. Ela apresentava um destino e um lugar social para as mulheres, o lugar da família, do doméstico, da dedicação ao trabalho artesanal no interior da casa, prescrevia o desenvolvimento de habilidades, veiculava tecnologias para a realização dos labores ditos femininos que se constituíam também em tecnologias do eu, tecnologias que insidiam no adestramento e constituição social de um dado corpo feminino. Na prescrição do que criar para vestir, na prescrição do tipo de roupas que deveriam cobrir os corpos femininos se distribuíam tecnologias de fabricação dos próprios corpos das mulheres. Mais uma vez, Maria Teresa Horta torna claro que o se vestir de saudade, o travestir-se de ser saudoso, o tomar o passado como máscara, como pré-texto é uma estratégia política no sentido de desmontar e desnaturalizar os discursos e práticas, muitas delas tidas como despretensiosas e inocentes, que seriam as mais perigosas e insidiosas, que constituíram as formas de ser, de dizer e de ver o feminino no presente. Fazer uma arqueogenealogia do presente, assim como enunciava Michel Foucault ${ }^{45}$, mapeando saberes, práticas, instituições, relações de poder que teriam instituído dadas verdades sobre o feminino, verdades que continuavam sendo assumidas e vividas pelas mulheres, como as de que mulher não tem desejo, que não 
aprecia o sexo, que não se masturba, que deseja sempre ser mãe, que se realiza no casamento e na maternidade, que deseja apenas um homem para casar, que não fala sobre sexo, a não ser que seja uma prostituta. As revistas femininas como a Modas e Bordados teriam funcionado como poderosos dispositivos para conformar as mulheres, notadamente as mais perigosas, aquelas que sabiam ler, aquelas das classes médias e abastadas, às expectativas do regime ditatorial em relação ao papel das mulheres na sociedade. Portanto, a estratégia política e discursiva da nova revista Mulheres, assumindo, assim, no próprio título a pluralidade dos femininos, era a de infundir vida a essa saudade, tratava-se de se vestir de uma saudade viva, vivificada pela própria crítica paródica, irônica, corrosiva dos sentidos estabelecidos, tarefa que Walter Benjamin, em suas teses sobre a história, reservava também aos historiadores. O trabalho de desmantelamento do senso comum, do sentido coletivamente partilhado, das verdades e das certezas sobre o ser feminino, dos estereótipos e preconceitos que condicionavam o cotidiano das mulheres passava pelo trabalho de deslocamento dos sentidos estabelecidos por tradições narrativas direcionadas às mulheres, como a tradição constituída pelas revistas e suplementos de jornais voltados para o público feminino, pela literatura para mulheres.

Essa preocupação pedagógica, de ensinamento e educação coletiva das mulheres portuguesas, de levar a elas uma reflexão sobre sua condição, que podemos vislumbrar nas ações e nos discursos de Maria Teresa Horta, se explicita antes mesmo da fundação desse periódico voltado ao público feminino. O seu livro de poesias publicado em 1975, o último de sua obra que gostaríamos de comentar nos limites desse texto, significativamente se intitulava Educação Sentimental e era dedicado em epígrafe a "todas as mulheres", nomeadas de "minhas irmãs" ". O título além de ser revelador de uma intenção educativa reafirma o caráter de paródia da tradição que caracteriza o trabalho dessa poetisa portuguesa, o seu trabalho de corrosão crítica da tradição, dos usos criativos e inventivos que faz do passado, da forma peculiar com que assume e lida com a tradição passadista e saudosista das próprias tradições narrativas e literárias, sejam nacionais, sejam internacionais. Mais uma vez ela se veste de saudade, ela coloca em seu corpo um vestido saudoso para retirá-lo pela cabeça, imagem recorrente e significativa em sua obra, que indica o uso da razão, da análise, da crítica como uma maneira de retirar esses vestidos, essas camadas de sentido, de verdades, de rotinas que agiriam como verdadeiras armaduras, carapaças configurando os corpos e as existências femininas. Ao mesmo tempo, esse gesto de retirar o vestido pela cabeça, de se liberar da roupa que encobre o seu corpo e desnudo oferecê-lo para o sexo, para o prazer, para o erotismo, simboliza também um gesto de liberação, gesto que não separa, como nunca aparece separado em sua obra, o corpo e o corpus de sua escritura: a boca do corpo é a boca da fala, da palavra, a boca que diz é a mesma que morde, lambe, chupa, saliva, a boca do discurso é a mesma dos gemidos. Na escrita 
ou na carne ela é portadora de sentidos, em seu texto a palavra é erótica, tem carnadura, é materialidade libidinal, na boca está a língua, objeto e sujeito de sentido e prazer:

Digo da boca do corpo/ uma rosa

a língua lenta/ e o suco da garganta

Gomo a gomo/ do útero/ a laranja

Pétala por pétala/ tecida a sua franja

O fio o fato/ tirado pela cabeça

A fimbria do vestido/ a fenda do vestido

As pernas cruzadas/ na racha entreaberta

Os braços erguidos/ e o vestido/ subido nas coxas que já

despe

Depois é a penumbra/ e o vestido/ a tirar pela cabeça/ amarrotado $^{47}$

O livro assume parodicamente o título do clássico da literatura francesa e ocidental, publicado em 1869, por Gustave Flaubert, onde assumindo o modelo do romance de formação, o personagem principal Fréderic Moreau conta as suas aventuras e desventuras amorosas, suas várias tentativas de estabelecer relações com mulheres, das mais diversas condições sociais e etárias, com mulheres casadas ou solteiras, virtuosas ou não. É a trajetória da constituição de um sujeito masculino, é a narrativa de seu aprendizado amoroso, de sua educação sentimental, da construção de sua própria subjetividade, em meio às grandes transformações sociais que ocorriam em seu país e que levaram à revolução de 1848 e à fundação do Segundo Império Francês ${ }^{48}$. Maria Teresa Horta assume ironicamente o lugar de Flaubert, um consagrado escritor, um homem famoso por ter produzido uma das figuras mais transgressivas e questionadoras do feminino na literatura do século XIX: Madame Bovary, para, assumindo sua máscara, desmascarar a misoginia que se encontrava presente em seus escritos. A galeria de mulheres que Flaubert cria em Educação Sentimental: a senhora Arnoux, a mulher mais velha e casada por quem o personagem se apaixona, a senhorita Vatnaz, que encontra em um cabaré de Paris, a vizinha interiorana e recatada Louise, Rosanette, a amante de luxo com quem se relaciona, a senhora Dambreuse a quem seduz buscando galgar posição social, seriam perfis femininos delineados pelo discurso masculino, lugares para o feminino que as mulheres para recusarem teriam que fazer a crítica por dentro do próprio discurso masculino. Não podendo haver um fora do discurso masculino, da língua masculina, caberia às mulheres se alojarem, se apropriarem desse discurso para dilacerá-lo, fragmentá-lo, para adulterá-lo desde dentro (o adultério feminino é um dos fantasmas que mais apavoram os homens por significar essa mudança de lugar, essa inversão do que seriam lugares fixos de sujeito). O caráter irônico de seu texto ainda se acentua à 
medida que o livro que promete tratar da educação sentimental, que prometia uma pedagogia do sentir, a prescrição de maneiras de aprender a sentir, de aprender a amar, como pretensamente seria o objetivo do livro do escritor francês, um homem em busca de aprender a amar as mulheres e que termina por fracassar, trata de como se educar o corpo, os sentidos, mais do que os sentimentos para o amor, inseparável de sua condição desejante e libidinal, como no discurso masculino, termina por tornar inseparável a dimensão afetiva da dimensão carnal, sexual do amor. O lugar comum da mulher que professa um amor idealizado, desencarnado, um amor espiritualizado, pudico, assexuado, um amor dito sublime, nobre, superior, um amor angelical (Maria Teresa Horta vai dedicar um livro a essa figura mitológica e pretensamente assexuada comumente associada às mulheres, o livro $O s$ Anjos $^{49}$, publicado em 1983, para ressaltar seu lado luciferino associando-o ao feminino, aquele que divide, que dilacera, que fende, que abre, o diabólico) é aí problematizado por uma poesia em que a educação sentimental é também educação dos sentidos, é sobretudo educação do corpo. O materialismo dialético de Maria Teresa Hora, seu aprendizado político feito com a literatura marxista, embora já articulado com a psicanálise, como aparecerá em Marcuse e Reich, traz para o centro de seu trabalho poético e político a centralidade do corpo, pela observação daquilo que a historiadora Anne Vincent-Buffaut ${ }^{50}$ chamou de economia dos signos corporais, pela atenção como a história marca e constitui as corporeidades, como o corpo feminino e masculino possuem camadas de sentido, como são constituídos por gestos, por hábitos, por condicionamentos que nascem de uma educação muitas vezes secular. O passado aparece à flor da pele, faz sintoma, torna-se gesto regular, torna-se costume, habitus como definiu Bourdieu ${ }^{51}$, o corpo é um palimpsesto de temporalidades e de espacialidades, de memórias arquivadas nas carnes, através de processos educacionais seculares pelos quais passou a espécie. Somos animais domados, civilizados, aculturados, e somente em dados momentos, como no sexo, na cópula, esse animal volta a se manifestar, a égua e o cavalo (imagens recorrentes em sua poesia) que há em nós se manifestam. O poema intitulado "Educação sentimental" que abre o livro explicita a ruptura operada, a traição à tradição romântica do romance de formação que ele significa, até mesmo por adotar a forma da poesia e não do romance e por ser uma narrativa fragmentada, construída com imagens dispersas, completamente distinta da narrativa romanesca, que constrói na continuidade de um relato uma dada imagem do tempo, de um tempo contínuo e teleológico presente na ideia de formação, correlato de ideias como a de progresso, evolução e desenvolvimento. É um tempo quase sempre do presente, do agora, do instante fugidio do prazer e do gozo, talvez resultado do presentismo que caracterizaria nosso regime de historicidade ${ }^{52}$ :

Põe devagar os dedos/ devagar... 


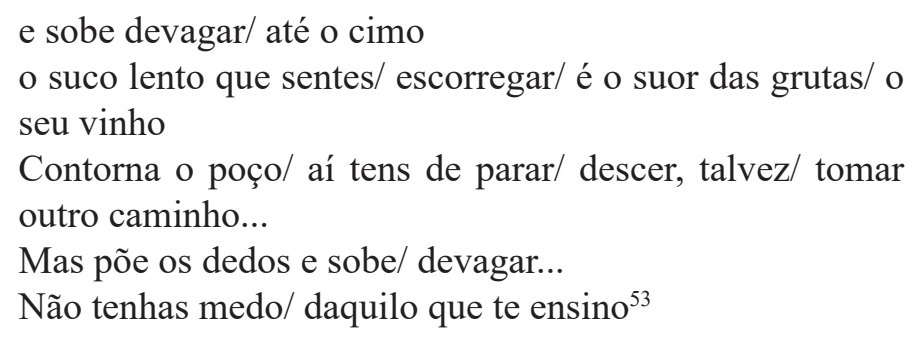

Por isso a saudade é na obra de Maria Teresa Horta ornamento, recurso retórico, porque a saudade não tem o condão de fazer durar, no sentido bergsoniano, esses momento fugazes de prazer, de felicidade, momentos únicos e irrepetíveis, momentos irrecuperáveis em que o ser se faz e se desfaz, em que o ser se dá e se recusa, em que o ser entra em transe, em transa e em transição para um fora, para uma dispersão do si mesmo, um ser que devém animal, homem, mulher, hermafrodita, anjo, demônio, feiticeira, deusa e humano demasiadamente humano. O tempo que emerge da poesia de Maria Teresa Horta é um tempo pontilhista, atravessado por agoras, pelo mesmo perigo do agora visualizado por Benjamin ${ }^{54}$, um agora que está saturado de outros tempos, que convoca e materializa imagens sobreviventes de outros tempos, que abre o presente para o devir, para o futuro, no mesmo momento que não deixa de ser, sempre, uma experiência de perda, de acabamento, de fim, de morte, portanto. No instante supremo do prazer, do gozo, do orgasmo, a vivência intensiva do tempo, um tempo ápice, um tempo suspenso, eterno por um instante, que logo dá lugar ao fim, ao pós-coito, sensação de morte, de saudade que logo se dá conta de seu fracasso em deter aquele instante, a saudade malograda e o malogro da saudade, a saudade malfadada é a tônica da obra de Maria Teresa Horta.

Deixando claro o desconhecimento do prazer e do corpo femininos por parte dos homens, o poema que abre o livro se refere ao próprio medo que esse desconhecimento provoca, o mistério e o segredo que seria o feminino para os homens, mistérios e segredos que o personagem de Flaubert não soube desvendar, mostrando tal inabilidade que terminou por fracassar e restar sozinho a chorar suas mágoas para outros homens, completamente entregue à saudade dos momentos fugazes e das figuras, tempos e espaços idealizados e só possíveis de serem vividos na memória como passados. Maria Teresa Horta constrói um eu lírico feminino que está no comando e domínio de seu corpo, de seu desejo, que pedagogicamente ensina o amante a descobrir os segredos e mistérios de seu corpo. Assim como no livro anterior Minha senhora de mim, podemos considerar que Educação sentimental é uma verdadeira escrita do corpo e com o corpo, uma construção poética do corpo feminino nascida da poética da sua própria materialidade. Todas as partes do corpo são aí descritas e convocadas como parte da constituição de um corpo erótico e sensível. Do corpo masculino 
centrado no falo, do prazer masculino centralizado nos genitais à construção de um corpo feminino descentrado, um corpo feminino constituído por distintas zonas erógenas, um corpo onde o prazer se faz da ponta do dedo à raiz dos cabelos, da nuca à vagina, das coxas às axilas, da língua aos pés, dos pulsos às ancas. Nesse corpo parece haver apenas um interdito, um não dito: o anus, jamais referido diretamente. Como num manual didático-pedagógico, diferentes maneiras de amar, de fazer amor, de gozar, de explorar as potencialidades infindas do corpo para produzir sensações são aí apresentadas, modos de amar são ensinados, várias modalidades de gozo são narrados, são disponibilizados como modelos de educação sentimental, uma educação sensível, voltada para as mulheres ainda presas a tabus e proibições que construíam corporeidades castradas, dessexualizadas, rotineiras e empobrecidas. Mas modos de amar que também são ensinados aos homens, ignorantes machistas, truculentos amantes, desconhecedores do próprio corpo e ainda mais do corpo feminino, estupradores cotidianos pela ignorância de seu corpo e do corpo do outro, exemplares de uma das formas mais contumazes da alienação social: a alienação do próprio corpo tornado mercadoria no capitalismo; corpos embrutecidos, brutalizados pelo trabalho, pelo exercício do poder, pela arrogância misógina:

\author{
Inclina os ombros \\ Deixa \\ as minhas mãos avançarem \\ na branda madeira \\ Na densa madeixa do teu ventre \\ Deixa \\ que te entreabra as pernas \\ docemente
}

Ondula mansamente a tua língua/ da saliva tirando/ toda a roupa

já breves vêm os dias/ dentro de noites/ tão poucas

o que vai restar do gozo/ se parares/ de me beijar? ${ }^{55}$

Se na Educação Sentimental de Flaubert há a promessa da formação, no futuro, de um sujeito masculino completo, acabado, finalmente encontrado com sua essência, com seu si mesmo, um ser capaz de unificar todas as suas experiências, de racionalizar o aprendizado trazido pela vida, fruto de uma história que seria mestra da vida, na Educação Sentimental de Maria Teresa Horta, o feminino parece mais se deformar, ganhar diferentes formas, formas passageiras e sem nenhuma essencialidade. $\mathrm{O}$ feminino parece ser uma procura, uma busca nunca plenamente satisfeita. As experiências femininas tendem à dispersão mais do que convergem para a formação de uma identidade, seja na vida, seja na linguagem; o feminino mais se desencontra do que se encontra. 
O recurso constante em sua obra a figuras que incorporariam o que seria o feminino, Lilith, Eva, as bruxas, as feiticeiras, não participam da ideia de um encontro com o chamado eterno feminino junguiano ${ }^{56}$. Essas figurações do feminino, como foram a freira Mariana Alcoforado ou sua ascendente D. Leonor, não são tomadas como modelo de uma essência feminina que deveria ser prolongada no presente, mas pelo contrário como maneiras de ser mulher que deveriam, ao ser historicizadas, localizadas no tempo, servir como recurso heurístico, como matéria para reflexão em relação à situação contemporânea das mulheres, à medida que se destacavam as continuidades e descontinuidades que as separavam do viver atual das mulheres, além de tomar delas o exemplo de transgressão, contestação, de ruptura com as regras do tempo de cada uma. Ao invés de aparecerem como modelos, elas seriam uma espécie de antimodelos para o ser feminino. Poderíamos dizer que há, em toda a obra de Maria Teresa Horta, essa procura, essa busca, essa saudade de um feminino original, primigênio, um feminino que talvez só pudesse ser encontrado na matéria bruta dos corpos, num corpo mítico anterior à civilização, um corpo feminino sagrado, um corpo de deusa, mas uma deusa, uma sacerdotisa à grega, entregue aos prazeres da carne:

Gota de água/ eu/ em tua boca

A matar-te a sede/ de solidão incerta

O que mais serei eu/ se apenas/ essa chuva

Gota aprisionada/ que logo se liberta? ${ }^{57}$

Mas a precariedade desse ser feminino, esse ser um fluxo, esse ser que se modifica com o tempo, esse ser que se diz historicamente, que se afirma no momento do delírio e do desejo, também afeta o ser masculino e as relações que com ele se possa estabelecer. O ser amado, o ser do amor é sempre uma interrogação, uma dúvida, é sempre precário pois temporal. Em sua poesia há uma espécie de revolta por acabar necessitando do outro, do masculino, do corpo outro para se realizar como mulher. A relação entre homens e mulheres, inclusive na relação sexual, é agônica, é trágica, é uma espécie de batalha em que ao requerer uma entrega, uma abertura, uma exposição, uma carência a/ de um outro, requer sair da identidade, do si mesmo para acolher a alteridade, para acolher intimamente um outro, significa a fragilização e a periclitação do sujeito que a duras penas se tentou construir, sua autonomia e sua liberdade. Uma raiva surda parece atravessar esse viver a dois, o viver desse encontro sempre desencontrado. O mito do andrógino, o mito platônico do encontro da outra metade da laranja (gomo e laranja são imagens recorrentes para descrever o ser amado), a busca do encontro com o único amor capaz de completar o outro (à medida que oferece todos os livros a seu marido a impressão é que tem com ele uma relação de muito amor e completude), é constantemente 
problematizado pela percepção de que não é possível um encontro, que dirá um regresso verdadeiro a ninguém, inclusive consigo mesmo. Os momentos de plenitude são fugazes, são epifânicos, gotas de eternidade destinadas rapidamente a desaparecer na boca do tempo, na voragem do tempo trazendo novamente a sede (imagem recorrente em sua poesia), a sede do outro e a sede de si mesma, a sede do desejo que nunca se satisfaz, que só estanca com a morte:

\author{
Ó meu amor minha raiva/ meu sol posto a rubro/ numa \\ praça \\ Minha voragem meu barco/ minha vingança de mar/ onde \\ me perco e me mato \\ Ó suicídio Ó silêncio/ O beber pelos teus braços/ respira a \\ tua boca/ precipício que desato \\ Ó corpo que sei ser meu/mas que me foge/ e não toco \\ Que voragem de dizer/ que prazer que não invoco/ de te \\ pensar e morrer/ de só te ter pouco a pouco \\ Ó ódio de bem te querer/ Ó ternura de ser tua \\ Ó vontade de correr/ contigo/ no meio da rua \\ Ó meu amor-desdizer/ Ó meu crime de mentira ${ }^{58}$
}

O amor, assim como o sujeito amoroso, assim como o ser amado são invenções discursivas, como aprendeu com o clássico livro de Roland Barthes ${ }^{59}$, são construções diárias, cotidianas, que obedecem a códigos de proceder e de dizer, são ilusões, são ficções reais porque acreditadas e vividas, mas que são por isso mesmo seres sem substância. Há em Maria Teresa Horta uma espécie de angústia, de raiva por saber que o ser de qualquer coisa se define no contraste com seu não-ser, é na diferença, é na contradição que o ser se diz, acima de tudo é no nada, é na morte que está a única verdade eterna do ser. A morte espreita a cama dos amantes, o ser do tempo é a transformação, é o desgaste daqueles corpos e de suas relações. Daí porque haveria em seus textos uma espécie de saudade de um fora do tempo, de uma eternidade para o ser, para o ser feminino, ser gerador da vida, ser primordial, ser que pare a todos e ao mundo por extensão, embora não fosse religiosa, embora não acreditasse em qualquer metafísica. Sua poesia era também parto, parto de seu mundo, parto de seu amado, parto de si mesma, de seu corpo, de seu desejo. Mas tudo aquilo que nasce está fadado a morrer, daí o apego à vida, aquilo que representa o sabor da vida, o prazer. Poesia epicurista, poesia hedonista, que chama atenção para as potências de vida do corpo antes que venha a morte. Se a essência da vida é a perda, o se perder no verso e o se perder no gozo é tudo que se pode ganhar na vida:

Quem pode adivinhar/ que conhecer-te assim/ é doloroso e frágil?

Ágil

Este constante perder-te/ sem jamais possuir/ a tua imagem ${ }^{60}$ 
A busca de completude, a busca da fusão com o ser amado, a busca da eternidade do tempo e do espaço do momento amoroso, a eternidade dos seres que se amam, objetivos míticos e supremos do amor romântico, aparecem ao mesmo tempo reafirmados como busca e negados como possibilidade. Da mesma forma que a descoberta do ser do masculino e do feminino como formas em constante negociação, tensão, elaboração, desmanchamento, gerando a sensação de precariedade. É uma regularidade do discurso de Maria Teresa Horta a ideia de ambiguidade, a recusa a se posicionar de um dado lado das divisões binárias que estruturam o pensamento ocidental, inclusive o pensamento amoroso. Ela opta por se colocar na fronteira, no limite, em habitar esse limbo, essa zona cinza, essa zona de sombra, onde as formas, tão bem delineadas da divisão vão perdendo nitidez, vão se esboroando, se encontrando, se esgarçando numa espécie de nevoeiro:

O que prossigo o que procuro/ ou digo/ desminto logo dentro do que faço

Este esquecer de mim/ por bem querer/ este te perder/ e envolver nos braços

Este meu dizer e desdizer/ de nunca te prender/ mas não esquecer que o faço

Este meu delírio/ minha febre/ este meu medo de saber

Este meu vício/ e minha causa/ este meu motivo/ de não ser ${ }^{61}$

Na relação amorosa dois seres que constantemente se perdem, perdem um ao outro, se perdem um no outro, perdem-se de si mesmos. Na busca do prender, o perder, na busca de apreender o ser com e na linguagem, o dizer e o desdizer constante. Presença de uma saudade constante de seres que se ausentam de si e do outro, seres que só podem gozar da fusão passageira do ato sexual, do encontro furtivo de fragmentos do tempo fadados a rapidamente passar. Em contradição com sua causa, com sua militância em torno da afirmação social do feminino, da construção de uma identidade política e social, com tendência essencialista para as mulheres, apanágio e aporia de todo movimento social, a carência que seu desejo instala, a falta que seu desejo constitui desse outro militantemente recusado e problematizado: o masculino. O vício, o viço tornando ambíguo e ambivalente o compromisso. $\mathrm{O}$ desejo, a carência do ser produzindo a carência de ser. O motivo, a paixão, o impulso de vida que a alojam no não ser. Constante ambiguidade, luta interior entre a razão, a consciência, o sujeito público, o sujeito político, e a paixão, o inconsciente, o desejo, o sujeito íntimo, o sujeito privado, o sujeito poético: a luta que poderia ser a definição mesma desse ser feminino, nesse momento histórico em que escreveu e viveu, ser sempre desencontrado consigo mesmo, esse ser saudoso de si. 
Carl Einstein ${ }^{62}$ recusava uma mera abordagem estética da obra de arte, à medida que a simples pergunta pela produção ou presença da beleza isolaria a obra de arte de seu contexto histórico e técnico, sacralizando-a, tornando um objeto de veneração. Para ele, qualquer obra de arte, inclusive a obra literária e poética deveria ser articulada com o "conjunto da história", o que chamava de fator extrínseco, e interrogada quanto a seus procedimentos próprios, o que seria o fator intrínseco, que condicionariam tanto o seu dispositivo formal, bem como a sua eficácia antropológica. Ou seja, para Carl Einstein a obra de arte deveria ser interrogada como "uma força viva e mágica" capaz não apenas de expressar, através de uma dada forma, dadas mensagens, mas capaz de afetar, de modificar a sensibilidade e a racionalidade individual e coletivas. As obras de arte, ao trazerem para o imaginário social novas imagens, novas elaborações, seriam forças "ativas e vivas" capazes de modificar o mundo humano, o mundo que habitamos, capazes de modificar cada um daqueles que com ela entrar em contato. Creio que é assim que Maria Teresa Horta entende e pratica a sua poesia, a sua escrita, que ela produz a sua obra, visando afetar o seu tempo e a sociedade em que vive. Se ela toma a sua arte como uma força viva, de vida, a saudade que nela aparece nunca é culto ao morto, ao ido, ao passado. Quando ela vai buscar na tradição formas, temas, personagens é para infundir-lhes, através de seu trabalho estético, uma nova vida, para vivificá-los, para fazêlos capazes de, novamente, afetar, fazer efeito, fazer um efeito novo e diverso sobre as sensibilidades e os imaginários de sua época, contribuindo para novas consciências se estabelecerem. Se, como várias vezes definiu, sua saudade é um ornamento, é uma máscara, é um vestido que ela retira pela cabeça, essa saudade é saudade viva, saudade que visa trazer e convocar novas maneiras de viver, notadamente para as mulheres. "Um dia vestida de saudade viva" para citar verso de uma famosa canção brasileira, ela tenta trazer vida, nova vida, para as mulheres que a leem, para as mulheres que com ela convivem. Tenta, com isso, afastar-se e afastá-las de dadas maneiras de ser mulher, de ser feminino, recusando a saudade que repõe a dominação masculina, rejeitando e revendo a tradição narrativa e história que a sustenta, denunciando o desejo pelo masculino, a necessidade física do outro, como essa saudade que não permite a definitiva liberdade das mulheres, que faz com que os gêneros sejam vividos como papeis agônicos, complementares e díspares, como essa luta interminável por ser algo que nunca se completa ou se sabe o que é, a luta interminável entre a mulher íntima e a mulher cidadã, a mulher da alcova e a mulher da cidade:

Afasto de ti com/ raiva surda o corpo/ as mãos/ o pensamento e apago secreta/ uma a uma/ as velas acesas do teu vento liberta ponho o corpo/ em seu lugar/ visto a cidade/ penteio um rio sedento penso ganhar/ e fujo/ e não entendo penso dormir/ mas não consigo/ o tempo 
E cede-se o vazio/ sobre o meu ventre

e segue-se a saudade/ em seu sustento

E digo este meu vício/ dos teus olhos/ de um verde tão lento/ muito lento

Se penso que te deixo/ já te quero

Se penso que recuso/ já te anseio

Se penso que te odeio/ já te espero

e torno a oferecer-te/ o que receio

Se penso que me calo/ já te grito

Se penso que me escondo/ já me ofereço

Se penso que não sinto/ é porque minto

Se pensas que me olhas/ já estremeço ${ }^{64}$

\section{NOTAS}

1HORTA, Maria Teresa. Cronista não é recado. In: Poesia Reunida. Lisboa: Dom Quixote, 2009, p. 257-298.

2 HORTA, Maria Teresa. Minha senhora de mim. In: Poesia Reunida, p. 301-350.

3 BARRENO, Maria Isabel; HORTA, Maria Teresa e COSTA, Maria Velho da. Novas cartas portuguesas. Lisboa: Dom Quixote, 2010.

4 HORTA, Maria Teresa. Educação sentimental. In: Poesia Reunida, p. 352-445.

5 FAUSTINO, Maria João. Maria Teresa Horta jornalista: percurso, memórias e circunstâncias. Comunicação Pública [Online]. Lisboa, vol. 9, n. 15, 2014. http://cp.revues.org/635. Acesso em 16 de junho de 2016

6 Ver: BARTHES, Roland. Mitologias. São Paulo: Difel, 1978.

7 HORTA, Maria Teresa. O homem empresta o seu corpo. In: Poesia Reunida, p. 267-268.

8 DERRIDA, Jacques. Gramatologia. São Paulo: Perspectiva, 2015.

9 REIS, Anderson Roberti e FERNANDES, Luiz Estevam de Oliveira. A crônica colonial como gênero de documento histórico. Ideias. Campinas, v. 2, n. 13, p. 25-41, 2006.

10 Para uma reflexão sobre a relação entre tempo e obra de arte ver: DIDI-HUBERMAN, Georges. Diante do tempo: história da arte e anacronismo das imagens. Belo Horizonte: UFMG, 2014.

11 HORTA, Maria Teresa. Tatuagem. In: Poesia 61. Faro: Tipografia Cácima, 1961, 5 fasc, p. $67-90$.

12 SILVEIRA, Jorge Fernandes da; MAFFEI, Luís (orgs.). Poesia 61 hoje. Rio de Janeiro: Oficina Raquel, 2011.

13 Ver: BARTHES, Roland. O prazer do texto. São Paulo: Perspectiva, 2002.

14 Conceito central na obra de: FOUCAULT, Michel. História da sexualidade I: a vontade de saber. Rio de Janeiro: Graal, 1977.

15 HORTA, Maria Teresa. Poema para os meus amigos. In: Poesia Reunida, p. 259.

16 HORTA, Maria Teresa. Memorial para a História. In: Poesia Reunida, p. 282.

17 MALATO, Maria Luísa. Grande entrevista: Maria Teresa Horta, menina. Revista Pontes de 
Vista [Online]. Lisboa, n. 1, 06 de abril de 2015. http://revistapontesdevista.com/2015/04/06/ maria-teresa-horta-menina/. Acesso em 16 de junho de 2016.

18 Casa Fronteira e Alorna. Associação dos Amigos da Torre do Tombo. http://www.aatt.org/ site/index.php?op=Nucleo\&id=1549. Acesso em 16 de junho de 2016.

19 HORTA, Maria Teresa. Crónica sobre o país seu rei e seu povo. In: Poesia Reunida, p. 284-285.

20 QUEIRÓS, Luís Miguel. Morreu o marquês de fronteira, um mecenas da cultura. Público [online]. Lisboa, 12 de novembro de 2014. http://www.publico.pt/culturaipsilon/noticia/ morreu-o-marques-de-fronteira-1676007. Acesso em 16 de junho de 2016.

21 HORTA, Maria Teresa. As Luzes de Leonor: a marquesa de Alorna, sedutora de anjos, poetas e heróis. Lisboa: Dom Quixote, 2011.

22 Ver: PASCOAES, Teixeira de. O homem universal e outros escritos. Lisboa: Assírio \& Alvim, 1993.

23 KLOBUCKA, Anna M. Mariana Alcoforado: formação de um mito cultural. Lisboa: INCM, 2006; ALCOFORADO, Soror Mariana. Cartas portuguesas. Lisboa: Assírio \& Alvim, 1998.

24 Ver: BENJAMIN, Walter. Teses sobre o conceito da história. In: Obras escolhidas 1: magia e técnica, arte e política. São Paulo: Brasiliense, 1987, p. 222-232.

25 Ver: DIDI-HUBERMAN, Georges. A imagem sobrevivente: a história da arte e tempo dos fantasmas segundo Aby Warburg. Rio de Janeiro: Contraponto, 2013.

26 HORTA, Maria Teresa. Retrato de uma fidalga de Lisboa. In: Poesia Reunida, p. 287-288.

27 Saudosismo (Caetano Veloso). Gal Costa, Philips, 1969.

28 ONFRAY, Michel. Cosmos: una antologia materialista. Buenos Aires: Paidós, 2016, p. 29.

29 CORBIN, Alain. Saberes e odores. São Paulo: Companhia das Letras, 1987.

30 FAUSTINO, Maria João. Op. Cit.

31 HORTA, Maria Teresa. Dama vestida de mim. In: Poesia Reunida, p. 305.

32Ver: SARAIVA, Antônio José. Iniciação à literatura portuguesa. São Paulo: Companhia de Letras, 1999.

33 HORTA, Maria Teresa. Regresso. In: Poesia Reunida, p. 301.

34 Idem. Ibidem.

35 HORTA, Maria Teresa. Cantiga sobre o lamento. In: Poesia Reunida, p. 305-306.

36 BITTENCOURT, Miriam Raquel Morante. A escrita feminina e feminista de Maria Teresa Horta. (Tese de Doutorado em Letras). Assis: Unesp, 2005.

37 HORTA, Maria Teresa. Minha saudade. In: Poesia Reunida, p. 306.

38 Entrevista com Maria Teresa Horta. http://poeticia.blogspot.com.br/2011/07/entevista-commaria-teresa-horta.html. Acesso em 16 de junho de 2016.

39 HORTA, Maria Teresa. A seu amigo. In: Poesia Reunida, p. 319.

40 HORTA, Maria Teresa. Espelho Inicial. In: Poesia Reunida, p. 29-58.

41 Ver: FOUCAULT, Michel. Outros Espaços. In: Ditos e escritos, vol. III. Rio de Janeiro: Forense Universitária, 2001, p. 411-422. 
42 LACAN, Jacques. A significação do falo. In: Escritos. Rio de Janeiro: Jorge Zahar, 1998, p. 692-703; FUENTES, Maria Josefina Sota. A mulher e seus nomes: Lacan e o feminino. (Tese de Doutorado em Psicologia). São Paulo, USP, 2009.

43 FAUSTINO, Maria João. Op. Cit.

44 Idem.

45 Ver: FOUCAULT, Michel. Nietzsche, a genealogia e a história. In: Microfisica do poder. 4 ed. Rio de Janeiro: Graal, 1984, p. 15-38.

46 HORTA, Maria Teresa. Educação sentimental. In: Poesia Reunida, p. 351.

47 HORTA, Maria Teresa. A boca do corpo. In: Poesia Reunids, p. 416.

48 FLAUBERT, Gustave. Educação sentimental. São Paulo: Martin Claret, 2006.

49 HORTA, Maria Teresa. Os anjos. Lisboa: Litexa Editora, 1983.

50 VICENTE-BUFFAULT, Anne. História das lágrimas. São Paulo: Paz e Terra, 1988.

51 BOURDIEU, Pierre. A economia das trocas simbólicas. São Paulo: Perspectiva, 1974.

52Para o conceito regime de historicidade ver: HARTOG, François. Regimes de historicidade: presentismo e experiências do tempo. Belo Horizonte: Autêntica, 2013.

53 HORTA, Maria Teresa. Educação sentimental. In: Poesia Reunida, p. 352.

54 BENJAMIN, Walter. Op. Cit.

55 HORTA, Maria Teresa. Modo de amar VI. In: Poesia Reunida, p. 429.

56 JUNG, Carl. Animus e anima. 12 ed. São Paulo: Cultrix, 1999.

57 HORTA, Maria Teresa. Gota de água. In: Poesia Reunida, p. 390.

58 HORTA, Maria Teresa. Poema de muito amor. In: Poesia Reunida, p. 327-329.

59 BARTHES, Roland. Fragmentos de um discurso amoroso. Rio de Janeiro: Francisco Alves, 1984

60 HORTA, Maria Teresa. Ágil. In: Poesia Reunida, p. 376.

61 HORTA, Maria Teresa. Sobre a ambiguidade. In: Poesia Reunida, p. 323-324.

62 EINSTEIN, Carl. Negerplastik. Florianópolis: Editora da UFSC, 2011.

63 Revelação (Fagner). Eu Canto - Quem viver chorará, CBS, 1978.

64 HORTA, Maria Teresa. Post Scriptum. In: Poesia Reunida, p. 349-350.

Artigo recebido em julho de 2016. Aceito em setembro de 2016. 